\title{
A Response to: Letter to the Editor Regarding 'Iron Formulations for the Treatment of Iron Deficiency Anemia in Patients with Inflammatory Bowel Disease: A Cost-Effectiveness Analysis in Switzerland'
}

\author{
Aysegül Aksan · Alain Schoepfer · Pascal Juillerat · Stephan Vavricka · \\ Miguel Bettencourt · Antonio Ramirez de Arellano · Simona Gavata • \\ Neige Morin · William J. Valentine · Barnaby Hunt
}

Received: September 10, 2021 / Accepted: November 16, 2021 / Published online: November 30, 2021

(C) The Author(s) 2021

Keywords: Cost; Cost-effectiveness; Inflammatory bowel disease; Iron deficiency anemia; Switzerland

\section{Dear Editor,}

We would like to thank the authors of the letter to the editor for sharing their thoughts on our article comparing the cost-effectiveness of ferric carboxymaltose (FCM), iron isomaltoside (IIM), iron sucrose (IS), and orally administered iron for the treatment of iron deficiency anemia (IDA) subsequent to inflammatory bowel disease (IBD) in Switzerland [1]. Open discussion such as this is a key part of the scientific process to ensure that analyses are fair and robust, which we believe our analysis to be [2]. The

\section{A. Aksan}

Interdisciplinary Crohn Colitis Centre, Rhein-Main, Frankfurt am Main, Germany

A. Aksan

Justus-Liebig University, Giessen, Germany

\section{A. Schoepfer}

Division of Gastroenterology and Hepatology, Centre Hospitalier Universitaire de Lausanne and

University of Lausanne, Lausanne, Switzerland

P. Juillerat

Gastroenterology, Clinic of Visceral Surgery and Medicine, Bern University Hospital, Bern, Switzerland letter to the editor raises concerns in four key areas, which we have addressed in turn below. We hope that the clarifications provided give additional helpful information to readers of Advances in Therapy.

\section{POPULATION}

The study used pooled data from two randomized controlled trials to inform the analysis. The authors of the letter to the editor raise the concern that this population may not be reflective of the population with IDA subsequent to IBD, citing that the Kulnigg et al. trial enrolled patients with hemoglobin $\leq 10 \mathrm{~g} / \mathrm{dL}$, which is a relatively low cutoff for the diagnosis of IDA $[3,4]$. As mentioned in the "Discussion"

S. Vavricka

Zentrum für Gastroenterologie und Hepatologie, Zürich, Switzerland

M. Bettencourt · N. Morin

Vifor Pharma Group, Villars-sur-Glâne, Switzerland

A. Ramirez de Arellano ( $₫)$. S. Gavata

Vifor Pharma Group, Flughofstrasse 61, 8152

Glattbrugg, Switzerland

e-mail: antonio.ramirez@viforpharma.com

W. J. Valentine $\cdot$ B. Hunt

Ossian Health Economics and Communications,

Basel, Switzerland 
section of the article, how well these randomized controlled trials reflect the Swiss population with IDA subsequent to IBD, particularly in terms of the key characteristics of body weight and hemoglobin, is currently difficult to assess. While the Swiss Inflammatory Bowel Disease Cohort Study (SIBDCS) collects and publishes data relating to various aspects of IBD in Switzerland (such as risk factors for developing IBD, risk factors for disease progression, fatigue in patients with IBD compared with the general population), the group is yet to publish data on the population with IDA subsequent to IBD [5-7]. We believe that the cohort characteristics used represent the best available option to reflect patients most in need of treatment for IDA subsequent to IBD, but acknowledge the uncertainty around these inputs, and therefore we conducted sensitivity analyses with alternative weight and hemoglobin values applied. It should also be noted that when the Ganzoni formula is used to calculate the iron dose, the product labels state that ideal body weight should be used in the calculation for overweight patients, with ideal body weight calculated based on a body mass index of $25 \mathrm{~kg} / \mathrm{m}^{2}$ [8-10]. Therefore the impact of this model parameter with regards to the percentage of patients with IDA subsequent to IBD that are overweight or obese in Switzerland will be much less than the authors of the letter suggest and unlikely to change the findings of our analysis.

The authors of the letter also raise the point of the use of standard errors rather than standard deviations in the analysis. This approach was intentionally chosen to narrow the range of body weight values used, as Switzerland has one of the lowest prevalence of overweight and obesity in Europe, and to reflect that ideal body weight should be used when the Ganzoni formula is applied to calculate the iron requirement [11]. To address the concerns of the authors of the letter to the editor, we have provided a reanalysis with standard deviations applied.

\section{METHOD TO ESTIMATE IRON REQUIREMENT IN EACH TREATMENT ARM}

In the base case analysis, the Ganzoni formula was used in the FCM arm, while the simplified dosing table was used in the IIM and IS arms. We then presented scenario analyses with the Ganzoni formula used in all treatment arms. The claim from the authors of the letter that these results are hidden from the reader is false, as they are clearly presented in Table 6 and discussed in the "Results" section on page 669. We believe that the results of these analyses cover the range of possible dosing methods, and that the reader has all of the information required to understand the analyses conducted and to select the results that they consider the most appropriate.

We dispute the contention in the letter that the same dosing method should be used to calculate the iron dose in all arms. The analysis aimed to apply the dosing calculation methods most commonly used in clinical practice in Switzerland, even if these differ across medications, in order to accurately reflect the costs accrued with each IV iron formulation. As the Ganzoni formula is the only option in the FCM label in Switzerland, this is clearly the appropriate choice in this treatment arm [8]. However, in the IIM arm, the choice is more nuanced, as both the simplified dosing table and the Ganzoni formula are options. Given that the simplified dosing table is recommended in the European Crohn's and Colitis Organisation (ECCO) guidelines and is an 
accepted option in the product label, we felt that this method of calculating the iron dose represents standard of care with IIM [12]. We concede that the Ganzoni formula should have been used in the IS arm in the base case, rather than in a sensitivity analysis, as this is recommended in the product label [12]. To address this, we have provided reanalyses using the following methods of calculating the iron dose, in line with the product labels:

- FCM: Ganzoni formula

- IIM: Simplified dosing table

- IS: Ganzoni formula

\section{LIMITATIONS OF THE NETWORK META-ANALYSIS}

Within the cost-effectiveness analysis, we have been open about the limitations of the network meta-analysis (NMA), as have the authors in the original NMA publication [13]. We choose to reference, rather than repeat, the previous discussion of the limitations of the NMA, as this is already in the public domain and would have added very little value to our article. It should be noted that the references used in the letter to the editor as part of the discussion of the limitations of the NMA are already included in the original cost-effectiveness article (Kennedy et al. 2017 and Reinisch et al. 2017) $[14,15]$.

\section{MEASURE OF EFFICACY}

We disagree with the authors of the letter when they state that $\mathrm{Hb}$ change is a more clinically informative measure of efficacy than response rate. The definition of response of an increase of at least $2 \mathrm{~g} / \mathrm{dL}$ or normalization of $\mathrm{Hb}$ reflects the ECCO guidelines for an acceptable response to iron supplementation treatment [10]. Furthermore, responder endpoints are used to assess the efficacy in randomized controlled trials of iron supplementation in patients with IDA subsequent to IBD, either as a primary or secondary endpoint $[3,4,16-18]$. As such, this endpoint provides useful information to clinicians on the relative efficacy.

An analysis using change from baseline in $\mathrm{Hb}$ data from an indirect comparison would have been susceptible to bias, as the increase in $\mathrm{Hb}$ would have been influenced by the baseline $\mathrm{Hb}$, with lower baseline $\mathrm{Hb}$ associated with a greater increase. The use of the responder endpoint based on an odds ratio is not subject to this confounding, as odds ratios are self-adjusting across the complete scale with respect to the location of the comparator group value.

Moreover, when conducting cost-effectiveness analyses, any health economist is constrained by the availability of data. The authors of the letter state that change from baseline in $\mathrm{Hb}$ should have been used, but currently there is no data source that could provide this for all relevant comparators, and therefore such an analysis would not be possible. The reader is free to assess the relevance of the responder endpoint used, the only endpoint that allows inclusion of all relevant comparators, and to draw their own conclusions.

\section{REANALYSIS}

A revised base case analysis using standard deviations to inform the sampling on inputs and with the methods of calculating the iron dose as described above is provided. This did not change the conclusions of the analysis (Tables 1, 2 and 3).

To further support this reanalysis, we have revised the scenario and sensitivity analyses. These showed minimal changes from the 
Table 1 Results of revised base case modeling analysis

\begin{tabular}{|c|c|c|c|c|}
\hline & $\begin{array}{l}\text { Ferric } \\
\text { carboxymaltose }\end{array}$ & Iron isomaltoside & Iron sucrose & $\begin{array}{l}\text { Orally } \\
\text { administered } \\
\text { iron }\end{array}$ \\
\hline Responders (\%) & $81(2)$ & $74(7)$ & $75(6)$ & $69(4)$ \\
\hline Iron dose $(\mathrm{mg})$ & $1332(430)$ & $1462(420)$ & $1332(430)$ & - \\
\hline Number of infusions & $1.9(0.5)$ & $1.7(0.2)$ & $7.2(2.2)$ & - \\
\hline Cost of treatment $(\mathrm{CHF})$ & $453(137)$ & $458(127)$ & $555(171)$ & $115(0)$ \\
\hline $\begin{array}{l}\text { Additional cost per additional responder } \\
\text { with ferric carboxymaltose versus the } \\
\text { comparator }\end{array}$ & & $\begin{array}{l}\text { Increased } \\
\text { responders with } \\
\text { reduced costs }\end{array}$ & $\begin{array}{l}\text { Increased } \\
\text { responders with } \\
\text { reduced costs }\end{array}$ & $\begin{array}{l}\text { CHF } 2901 \text { per } \\
\text { additional } \\
\text { responder }\end{array}$ \\
\hline
\end{tabular}

CHF, 2020 Swiss Francs. Response was defined as a patient who achieved normalization of hemoglobin levels or an increase in hemoglobin of $\geq 2 \mathrm{~g} / \mathrm{dL}$. Values are mean (standard deviation)

Table 2 Results of revised scenario analysis

Additional cost per additional responder with ferric carboxymaltose versus the comparator

\begin{tabular}{lll}
\hline $\begin{array}{l}\text { Ferric } \\
\text { carboxymaltose }\end{array}$ & $\begin{array}{l}\text { Ferric } \\
\text { carboxymaltose }\end{array}$ & $\begin{array}{l}\text { Ferric carboxymaltose } \\
\text { versus orally } \\
\text { versus iron }\end{array}$ \\
versus iron & administered iron \\
isomaltoside & sucrose & \\
\hline
\end{tabular}

Microcosting approach

Base case analysis (Ganzoni formula used in the ferric carboxymaltose and iron sucrose arms, simplified dosing table used in iron isomaltoside arm)

Ganzoni formula used in all arms

TARMED costing approach

Ganzoni formula used in the ferric carboxymaltose and iron sucrose arms, simplified dosing table used in iron isomaltoside arm

Ganzoni formula used in all arms
Increased responders with reduced costs

Increased responders with reduced costs
CHF 303 per additional responder
CHF 819 per additional responder

Increased responders with reduced costs

Increased responders with reduced costs

$$
\begin{aligned}
& \text { Increased } \\
& \text { responders with } \\
& \text { reduced costs }
\end{aligned}
$$

Increased responders with reduced costs
CHF 2901 per additional responder

CHF 2901 per additional responder 
Table 3 Results of revised sensitivity analysis

\begin{tabular}{|c|c|c|c|}
\hline & \multicolumn{3}{|c|}{ Additional cost per additional responder with ferric carboxymaltose versus the comparator } \\
\hline & $\begin{array}{l}\text { Ferric carboxymaltose versus } \\
\text { iron isomaltoside }\end{array}$ & $\begin{array}{l}\text { Ferric carboxymaltose } \\
\text { versus iron sucrose }\end{array}$ & $\begin{array}{l}\text { Ferric carboxymaltose versus } \\
\text { orally administered iron }\end{array}$ \\
\hline Base case analysis & $\begin{array}{l}\text { Increased responders with } \\
\text { reduced costs }\end{array}$ & $\begin{array}{l}\text { Increased responders with } \\
\text { reduced costs }\end{array}$ & CHF 2901 per additional responder \\
\hline $\begin{array}{l}\text { Upper } 95 \% \mathrm{CI} \text { of } \\
\text { odds ratios }\end{array}$ & $\begin{array}{l}\text { Reduced responders with } \\
\text { reduced costs }\end{array}$ & $\begin{array}{l}\text { Equal responders with } \\
\text { reduced costs }\end{array}$ & $\begin{array}{l}\text { CHF } 16,686 \text { per additional } \\
\text { responder }\end{array}$ \\
\hline $\begin{array}{l}\text { Lower } 95 \% \mathrm{CI} \text { of } \\
\text { odds ratios }\end{array}$ & $\begin{array}{l}\text { Increased responders with } \\
\text { reduced costs }\end{array}$ & $\begin{array}{l}\text { Increased responders with } \\
\text { reduced costs }\end{array}$ & CHF 1468 per additional responder \\
\hline $\begin{array}{l}\text { Body weight } \\
\text { increased by } 10 \mathrm{~kg}\end{array}$ & $\begin{array}{l}\text { Increased responders with } \\
\text { reduced costs }\end{array}$ & $\begin{array}{l}\text { Increased responders with } \\
\text { reduced costs }\end{array}$ & CHF 3086 per additional responder \\
\hline $\begin{array}{l}\text { Hemoglobin } \\
\text { increased by } 1 \mathrm{~g} / \\
\mathrm{dL}\end{array}$ & $\begin{array}{l}\text { Increased responders with } \\
\text { reduced costs }\end{array}$ & $\begin{array}{l}\text { Increased responders with } \\
\text { reduced costs }\end{array}$ & CHF 2488 per additional responder \\
\hline $\begin{array}{l}\text { Hemoglobin } \\
\text { decreased by } 1 \mathrm{~g} / \\
\mathrm{dL}\end{array}$ & $\begin{array}{l}\text { CHF } 364 \text { per additional } \\
\text { responder }\end{array}$ & $\begin{array}{l}\text { Increased responders with } \\
\text { reduced costs }\end{array}$ & CHF 3385 per additional responder \\
\hline $\begin{array}{l}\text { All pharmacy } \\
\text { costs }+10 \%\end{array}$ & $\begin{array}{l}\text { Increased responders with } \\
\text { equal costs }\end{array}$ & $\begin{array}{l}\text { Increased responders with } \\
\text { reduced costs }\end{array}$ & CHF 3180 per additional responder \\
\hline $\begin{array}{l}\text { All pharmacy } \\
\text { costs }-10 \%\end{array}$ & $\begin{array}{l}\text { Increased responders with } \\
\text { reduced costs }\end{array}$ & $\begin{array}{l}\text { Increased responders with } \\
\text { reduced costs }\end{array}$ & CHF 2582 per additional responder \\
\hline
\end{tabular}

CHF, 2020 Swiss Francs; CI, credible interval. Response was defined as a patient who achieved normalization of hemoglobin levels or an increase in hemoglobin of $\geq 2 \mathrm{~g} / \mathrm{dL}$

original article, demonstrating the robustness of the conclusions drawn on the basis of the cost-effectiveness modeling.

\section{CONCLUSION}

In summary, the authors believe that the analysis described in our article is based on the best available data, applied with appropriate assumptions, for a cost-effectiveness evaluation in Switzerland. Many of the points raised in the letter to the editor were discussed at length during the preparation of our analysis and, where relevant, have been mentioned in the article. The reanalyses have shown that using the alterative assumptions suggested in the letter to the editor (regardless of whether they are appropriate or not) would not substantially change the findings of the cost-effectiveness analysis.

\section{ACKNOWLEDGEMENTS}

Funding. The study was supported by funding from Vifor Pharma Group. No funding or sponsorship was received for the publication of this response letter.

Authorship. All named authors meet the International Committee of Medical Journal Editors (ICMJE) criteria for authorship for this article, take responsibility for the integrity of 
the work as a whole, and have given their approval for this version to be published.

Author Contributions. All author contributed to the study concept and design. Data were acquired by Aysegül Aksan, Miguel Bettencourt, Antonio Ramirez de Arellano and Simona Gavata. Analyses were performed by Barnaby Hunt. The article was drafted by Barnaby Hunt, and revised by all other authors.

Disclosures. Aysegül Aksan has received consulting or speaker fees from the following Immundiagnostik and Vifor Pharma, and research funding from Immundiagnostik. Alain Schoepfer has received consulting or speaker fees from the following companies: Abbvie, Dr Falk Pharma, MSD, Pfizer, Regeneron, Takeda, UCB, and Vifor Pharma. Pascal Juillerat declared no conflict of interest. Stephan Vavricka has received consulting or speaker fees from the following companies: Abbvie, Dr Falk Pharma, Ferring, Gilead, iQuone, Janssen, MSD, Pierre Fabre, Pfizer, Regeneron, Sanofi, Takeda, Tillotts, UCB, and Vifor Pharma. Miguel Bettencourt, Antonio Ramirez de Arellano, Simona Gavata and Neige Morin are employees of Vifor Pharma Group. William J Valentine and Barnaby Hunt are employees of Ossian Health Economics and Communications, which received consulting fees from Vifor Pharma Group to support preparation of the analysis.

Compliance with Ethics Guidelines. This article is based on previously conducted studies and does not contain any studies with human participants or animals performed by any of the authors.

Data Availability. The datasets generated during and/or analyzed during the current study are available from the corresponding author on reasonable request.

Open Access. This article is licensed under a Creative Commons Attribution-NonCommercial 4.0 International License, which permits any non-commercial use, sharing, adaptation, distribution and reproduction in any medium or format, as long as you give appropriate credit to the original author(s) and the source, provide a link to the Creative Commons licence, and indicate if changes were made. The images or other third party material in this article are included in the article's Creative Commons licence, unless indicated otherwise in a credit line to the material. If material is not included in the article's Creative Commons licence and your intended use is not permitted by statutory regulation or exceeds the permitted use, you will need to obtain permission directly from the copyright holder. To view a copy of this licence, visit http://creativecommons.org/licenses/by$\mathrm{nc} / 4.0 /$.

\section{REFERENCES}

1. Aksan A, Schoepfer A, Juillerat P, et al. Iron formulations for the treatment of iron deficiency anemia in patients with inflammatory bowel disease: a cost-effectiveness analysis in Switzerland. Adv Ther. 2021;38:660-77. https://doi.org/10.1007/ s12325-020-01553-1.

2. Muñoz M, Reinisch W. Iron formulations for the treatment of iron deficiency anemia in patients with inflammatory bowel disease: A cost-effectiveness analysis in Switzerland. Adv Ther. https://doi. org/10.1007/s12325-021-02000-5

3. Evstatiev R, Marteau P, Iqbal T, et al. FERGIcor, a randomized controlled trial on ferric carboxymaltose for iron deficiency anemia in inflammatory bowel disease. Gastroenterology. 2011;141(3):846853.e1-2.

4. Kulnigg S, Stoinov S, Simanenkov V, et al. A novel intravenous iron formulation for treatment of anemia in inflammatory bowel disease: the ferric carboxymaltose (FERINJECT) randomized controlled trial. Am J Gastroenterol. 2008;103(5): 1182-92.

5. Lautenschlager SA, Fournier N, Biedermann L, et al. The influence of breastfeeding, cesarean section, pet animals, and urbanization on the development of inflammatory bowel disease: data from the Swiss IBD cohort study. Inflamm Intest Dis. 2020;5(4): 170-9.

6. Ditrich F, Blümel S, Biedermann L, et al. Genetic risk factors predict disease progression in Crohn's disease patients of the Swiss inflammatory bowel disease cohort. Therap Adv Gastroenterol. 2020;13: 1756284820959252. 
7. Schreiner P, Rossel JB, Biedermann L, et al. Fatigue in inflammatory bowel disease and its impact on daily activities. Aliment Pharmacol Ther. 2021;53(1):138-49.

8. Compendium.ch. FERINJECT Inj Lös $100 \mathrm{mg} / 2 \mathrm{ml}$. 2021. https://compendium.ch/product/1080875ferinject-inj-los-100-mg-2ml/mpro. Accessed 17 July 2020.

9. Compendium.ch. MONOFER Inj Inf Präp $100 \mathrm{mg} /$ $\mathrm{ml}$ (iH 12/19). 2021. https://compendium.ch/ product/1423093-monofer-inj-inf-prap-100-mg-ml/ mpro. Accessed 17 July 2020.

10. Dignass AU, Gasche C, Bettenworth D, et al. European consensus on the diagnosis and management of iron deficiency and anaemia in inflammatory bowel diseases. J Crohns Colitis. 2015;9(3):211-22.

11. World Health Organization. Nutrition, Physical Activity and Obesity: Switzerland. 2013. https:// www.euro.who.int/_data/assets/pdf_file/0004/ 243328/Switzerland-WHO-Country-Profile.pdf. Accessed 15 June 2021.

12. Compendium.ch. VENOFER Inj Lös $100 \mathrm{mg} / 5 \mathrm{~m}$. 2021. https://compendium.ch/product/46040venoferinj-los-100-mg-5ml/mpro. Accessed 17 July 2020 .

13. Aksan A, Isık H, Radeke HH, Dignass A, Stein J. Systematic review with network meta-analysis: comparative efficacy and tolerability of different intravenous iron formulations for the treatment of iron deficiency anaemia in patients with inflammatory bowel disease. Aliment Pharmacol Ther. 2017;45(10):1303-18.

14. Kennedy NA, Goodhand JR, Rampton DS. Editorial: which iron preparation for patients with IBD? Aliment Pharmacol Ther. 2017;46(2):194-5.

15. Reinisch W, Lindgren S. Letter: the importance of dosing and baseline haemoglobin when establishing the relative efficacy of intravenous iron therapies. Aliment Pharmacol Ther. 2017;46(7):704-5.

16. Lindgren $\mathrm{S}$, Wikman $\mathrm{O}$, Befrits $\mathrm{R}$, et al. Intravenous iron sucrose is superior to oral iron sulphate for correcting anaemia and restoring iron stores in IBD patients: a randomized, controlled, evaluator-blind, multicentre study. Scand J Gastroenterol. 2009;44(7):838-45.

17. Reinisch W, Staun M, Tandon RK, et al. A randomized, open-label, non-inferiority study of intravenous iron isomaltoside 1,000 (Monofer) compared with oral iron for treatment of anemia in IBD (PROCEED). Am J Gastroenterol. 2013;108(12): 1877-88.

18. Schröder O, Mickisch $\mathrm{O}$, Seidler $\mathrm{U}$, et al. Intravenous iron sucrose versus oral iron supplementation for the treatment of iron deficiency anemia in patients with inflammatory bowel disease: a randomized, controlled, open-label, multicenter study. Am J Gastroenterol. 2005;100(11):2503-9. 